\title{
Pelayanan Kebutuhan Narapidana Kelompok Rentan Penyandang Disabilitasi Di Lapas Kelas 1 Madiun
}

\author{
Muhammad Fardhil Prismawan', Mitro Subroto \\ Politeknik Ilmu Pemasyarakatan, Depok \\ E-Mail : fardhil123@gmail.com \\ Politeknik Ilmu Pemasyarakatan \\ E-Mail : subrotomitro07@gmail.com
}

\begin{abstract}
Dimana pada saat situasi yang tidak stabil ini penyebab hilangnya harkat martabat dan kedudukan sebagi penyandang disabilitas khususnya di Lembaga Pemasyarakatan. Merupakan kewajiban negara dalam menjamin hakhak yang harus terprnuhi oleh para penyandang disabilitas sesuai dengan undang-undang yang telah berlaku. Dalam rangka memenuhi pelayanan publik terhadap penyandang disabilitas perlu adanya keseteraan perlakuan dengan masyarakat pada umumnya. Hal ini dilakukan bukan semata-mata bertujuan melindungi Hak Asasi Manusia setiap orang, tetapi juga melaksanakan amanat yang terdapat dalam undang-undang dan sebagai penghormatan martabat manusia. Tentu dalam memberikan pelayanan publik berupa program pembinaan dan kepribadian bagi narapidana khususnya penyandang disabilitas, tentu Lapas sebagai tempatnya diharapkan dapat memberikan hak bagi narapidana penyandang disabilitas. Karena dalam hal ini Lapas merupakan fasilitas umum, yang artinya sama seperti fasilitas pada umumnya dalam memberikan pelayanan harus memenuhi persamaan hak asasi manusia
\end{abstract}

Keywords — : Penyandang disabilitas, kelompok rentan, narapidana, pelayanan

\section{PENDAHULUAN}

Kelompok rentan adalah kelompok dimana masyarakat yang memiliki resiko tinggi, karena dalam melakukan aktivitas dalam situasi dan kondisi tertentu kurang memiliki keterbatasan dalam mempersiapkan ancaman resiko tinggi. Kelompok rentan idealnya mendapatkan perhatian khusus oleh pemerintah jug berbagai pihak, yang mana yang sudah tercantum dalam UU No. 39 Tahun 1999. Di dalam Lembaga Pemasyarakatan yang masuk dalam kategori kelompok rentan yaitu: Perempuan, lansia, penyandang disabilitas, anak-anak, narapidana dengan putusan seumur hidup, dan narapidana dengan putusan seumur hidup.

Setiap manusia memiliki hak yang sama dimata hukum dan tidak ada perlakuan yang diskriminatif seperti, kekerasan fisik, perbuatan rasial, kecacatan, semua manusia diperlakukan sama di mata hukum.

Menurut Harbani Pasolong (2007:128) Pelayanan Publik merupakan setiap kegiatan yang dilakukan oleh pemerintah terhadap sejumlah manusia dimana disetiap kegiatan menguntungkan dalam suatu kesatuan atau kumpulan, dan menawarkan kepuasaan meskipun hasilnya tidak terikat pada suatu produk secara fisik.

Berdasarkan dalam Undang-undang Nomor 8 Tahun 2016 tentang penyandang disabilitas pada pasal 1 ayat 1 berbunyi bahwa Penyandang disabilitas merupakan setiap manusia yang mengalami keterbatasan fisik, intelektual, mental, atau sensorik dalam jangka waktu yang lama dalam berinteraksi dengan lingkungan dapat mengalami gangguan dan kesulitan untuk turut berperan secara penuh dan efektif dengan warga negara lainnya berdasarkan persamaan hak. Jika penyandang disabilitas melakukan tindak pidana, maka konsekuensi yang diterima oleh penyandang disabilitas juga harus melalui proses hukum yang berlaku, serta lapas dijadikan tempat menjalani masa pidana jika terbukti bersalah. Hal ini disebabkan oleh tindak pidana yang sama sekali tidak dapat di hapus oleh masyarakat, melainkan hanya dapat dihapuskan sampai mencapai batas-batas toleransi.

Penyandang disabilitas pada dasarnya harus mendapatkan jaminan perlindungan hukum baik di tingkat persidangan atau saat menjalani masa pidana (narapidana). Oleh karena itu jaminan perlindungan terhadap penyandang disabilitas tidak hanya saat pra ajudikasi, ajudikasi melaikan juga pada tingkat paska ajudikasi.

Bagi narapidana penyandang disabilitas dalam menjalani masa pidana di lapas akan memperoleh hak spesial khususnya di pelayanan karena keterbatasannya. Maka dari itu bagi narapidana penyandang disabilitas mendapatkan pelayanan yaitu aksesbilitas. Dalam pasal 1 ayat 8 UU Nomor 8 Tahun 2016 menjelaskan bahwa aksesbilitas merupakan kemudahan yang telah disediakan untuk penyandang disabilitas guna mewujudkan Kesamaan 
Kesempatan. Tujuan aksesbilitas adalah agar mempemudah penyandang disabilitas dalam menjalani aktivitas dan memiliki akses pelayanan publik, sedangkan bagi narapidana yang sedang menjalani masa pidana memperoleh program pembinaan sesuai keterbatasan yang dimiliki narapidana tersebut. Dengan demikian penyandang disabilitas khususnya narapidana memiliki hak atas pelayanan sosial dalam meningkatkan rasa kemandirian.

Maka Pemerintah dalam hal ini khususnya Direktorat Jenderal Pemasyarakatan diharapkan agar berupaya mendorong UPT Lapas dan Rutan memberikan perhatian khusus dan pelayanan kepada narapidana penyandang disabilitas. Dan pada intinya yaitu dapat tercapainya aksesbilitas terhadap pelayanan publik dan fasilitas publik bagi narapidana penyandang disabilitas di dalam Lapas.

\section{METODE PENELITIAN}

Dalam penelitian ini memakai metode hukum empiris, dimana dalam penelitiaannya tidak hanya meneliti normanya saja, akan tetapi juga meneliti bagaimana penarapan normanya, yaitu berkaitan dengan perlindungan serta pemenuhan hak-hak para penyandang disabilitas. Data yang saya gunakan dalam penelitian ini yaitu primer dan sekunder. Informasi data primer di penelitian didapatkan dari Undang-Undang tentang narapidana penyandang disabilitas yang telah diatur oleh pemerintah Indonesia, sedangkan informasi data sekunder diperoleh dari informasi jurnal, dokumen registrasi Lapas Kelas 1 Madiun, wawancara dengan responden yakni narapidana penyandang disabilitas. Penelitian ini lebih menggambarkan bagaimana kondisi, manusia, dan lain-lain yang berhubungan dengan narapidana disabilitas seakurat mungkin.

\section{HASIL DAN PEMBAHASAN}

Lembaga Pemasyarakatan merupakan penegak hukum yang fungsinya sebagai pelaksana pidana dari putusan pengadilan yang berupa pidana penjara. Lembaga pemasyarakatan masuk dalam UPT pelaksana teknis di Kementerian Hukum dan HAM merupakan intrumen pemerintah atau aparat pemerintah. Dimana narapidana dalam menjalani masa pidana mendapat pembinaan agar dapat memiliki skill agar dapat kembali ke masyarakat dan dapat berguna bagi nusa dan bangsa.

Pembinaan bagi narapidana harus berlandaskan hukum yang sesuai dengan Pancasila dan dilaksanakan dengan baik. Dalam melakukan pembinaan bagi narapidana harus dibina dengan baik, taat pada aturan, meningkatkan kualitas dengan mengolah skill sesuai keahlian yang dimiliki dengan mengikuti program kerja dari Lapas.

Orang yang menyandang disabilitas yaitu orang yang mempunyai keterbatasan sensorik, intelektual, fisik, dan spiritual, akibat bagi narapidana penyandang disabilitas akan memiliki kesulitan dalam berpartisipasi dan berinteraksi di lingkungan Lapas. Yang tentunya bagi narapidana penyandang disabilitas memiliki kekurangan dalam melaksanakan progam pembinaan kepribadian dan kemandirian yang diberikan oleh pihak Lapas.

WHO (World Health Organization) menerbitkan International Classification Functioning, Disability, and Health (ICF). ICF ini menjelaskan adanya faktor lingkungan yang menjadi penyebab terjadinya disabilitas. Di ICF permasalahan terkait fungsi manusia dikelompokkan menjadi tiga kategori yang saling berhubungan, yaitu:

A. Keterbatasan fisik: permasalahan fungsi badan atau perubahan pada struktur badan, misalnya paralisis atau kebutaan.

B. Keterbatasan aktivitas: hambatan dalam melakukan kegiatan, misalnya berjalan atau makan.

C. Pembatasan partisipasi: permasalahan dalam keterlibatan dalam berbagai kehidupan, misalnya diskriminasi dalam pekerjaan.

Penyandang cacat tubuh adalah kelainan tubuh yang dimiliki seseorang pada alat gerak meliputi otot, struktur atau fungsinya dan persendian yang dapat menganggu atau menghambat aktivitas sehari-hari. Jenis kecacatan pada penyandang cacat tubuh dibedakan menjadi:

- Putus (amputasi) pada kaki ataupun tangan

- Cacat tulang punggung

- Cacat persendian, tungkai

- TBC tulang dan sendi

- Paraplegia

- Cerebral palcy (cacat koordinasi dari gerak anggota badan yang terganggu)

- Cacat sakit folio 
Sedangkan berdasarkan derajat kecacatannya dibedakan menjadi:

a. Cacat tubuh ringan

Dimana penyandang cacat dalam melakukan aktivitas sehari hari tidak memerlukan bantuan dari orang lain. Golongan penyandang cacat tubuh ini sebagai berikut amputasi tangan dan kaki, layuh salah satu kaki, tangan atau kaki yang bengkok, cerebral pacly ringan

b. Cacat tubuh sedang

Penyandang cacat tubuh ini dimana dalam melakukan aktivitas dan kegiatan sehari hari perlu dilatih terlebih dahulu sehingga kedepannya dapat dilakukan tanpa pertolongan orang lain. Berikut yang termasuk golongan ini adalah amputasi kedua tangan atas siku, skiolosis, cerebral palcy sedang.

c. Cacat tubuh berat

Penyandang cacat ini dalam situasi dan kondisi apapun harus dan selalu memerlukan bantuan dari orang dalam melakukan aktivitas dan kegiatan sehari hari. Yang termasuk golongan ini adalah sebagai berikut amputasi dua kaki atas lutut dan dua tangan atas siku, layuh dua kaki dan dua tangan, paraplegia berat dan sebagainya.

Berikut data yang disajikan narapidana penyandang disabilitas di Lembaga Pemasyarakatan Kelas 1 Madiun:

\begin{tabular}{|c|c|c|c|}
\hline Blok & Kamar & Kondisi Disabilitas & Jumlah \\
\hline H & H1 & Kaki & 1 orang \\
\hline B & B7 & Kaki & 1 orang \\
\hline Penaling & P1 & Kaki & 1 orang \\
\hline B & B9 & Tulang Punggung & 1 orang \\
\hline E & E3 & Kaki & 1 orang \\
\hline E & E5 & Leher+Tulang punggung & 1 orang \\
\hline E & E7 & Tangan & 1 orang \\
\hline G & G1 & Step & 1 orang \\
\hline E & E7 & Mata & 1 orang \\
\hline
\end{tabular}

Dari data tersebut diketahui Lembaga Pemasyarakatan dalam melaksanakan program pembinaan bagi narapidana disabilitas diharapkan memenuhi kebutuhan-kebutuhan penunjang bagi narapidana penyandang disabilitas agar dapat menjalani aktivitas seperti narapidana pada umumnya.

Narapidana penyandang disabilitas membutuhkan kebutuhan khusus agar dapat beraktivitas layaknya narapidana lainnya, berikut kebutuhan pelayanan sosial bagi narapidana penyandang disabilitas:

1. Kebutuhan narapidana yang menyandang disabilitas sebagai individu

Bagi narapidana yang menyandang disabilitas pengakuan/sikap penerimaan dari narapidana lain dan petugas pemasyarakatan merupakan suatu kebutuhan untuk setiap orang yang diakui keberadaannya serta dihargai sebagai individu. Dengan diakui dan dihargai narapidana penyandang disabilitas tentu merasa aman dalam menjalani masa pidana di lapas.

Prinsip dalam pekerjaan sosial merupakan dasar "penerimaan", yang mana merupakan prinsip dalam memberikan tuntunan sosial kepada narapidana penyandang disabilitas sebagai individu. Hal ini bermaksud petugas bidang kegiatan kerja di lapas dapat dalam melaksanakan pendampingan bisa menerima pada umumnya sesuai keadaan. Maka dari itu narapidana penyandang disabilitas merasa senang dan lebih aman sehingga cepat dalam proses menyesuaikan diri di lingkungan kehidupannya.

2. Kebutuhan narapidana penyandang disabilitas sebagai makhluk sosial

Narapidana yang menyandang disabilitas tidak hanya memerlukan rasa aman, diakui keberadaannya sebagai individu tetapi juga memerlukan pengakuan sebagai makhluk sosial yang dapat diterima serta berpatisipasi aktif dalam masyarakat. Kesadaran narapidana lain dalam menerima narapidana penyandang disabilitas berguna menjadi motivasi tumbuhnya kepercayaan diri narapidana penyandang disabilitas. Dengan itu fungsi sosial bagi narapidana disabilitas diharapkan dapat optimal guna menunjang program pembinaan yang ada di dalam lapas.

3. Kebutuhan narapidana penyandang disabilitas dalam masyarakat

Keterbukaan fikiran serta pengakuan kepada masyarakat terhadap keberadaan yang menyandang disabilitas merupakan motivasi hidup bagi mereka, hal ini sejalan juga dengan kehidupan narapidana yang menyandang disabilitas. Narapidana yang menyandang disabilitas diharapkan dapat menciptakan dampak yang andil bagi 
masyarakat luas setelah menjalani masa pidana meskipun memiliki kekurangan. Karena didalam Lapas selama menjalani masa pidana mereka mendapatkan pembinaan dari petugas pemasyarakatan agar narapidana memiliki skill.

4. Kebutuhan pelayanan umum/aksesbilitas

Sarana aksesbilitas yang tersedia di lapas merupakan kebutuhan bagi narapidana disabilitas. Pemenuhan pelayanan ini sangat berpengaruh dalam pemberian dukungan yang terhadap proses kegiatan dan keberhasilan dalam program pembinaan yang dilakukan oleh Lapas.

Narapidana penyandang disabilitas mendapat jaminan perlindungan hukum yang tercantum didalam Undang-Undang Nomor 8 Tahun 2016 tentang Penyandang Disabilitas pada pasal 37, yaitu fungsi Unit Layanan Disabilitas:

A. Tersedia pelayanan masa adaptasi bagi tahanan yang menyandang Disabilitas selama 6 (enam) bulan;

B. Menyediakan kebutuhan khusus, seperti obat- obatan yang melekat pada tahanan yang menyandang Disabilitas dalam masa tahanan dan pembinaan; dan

C. Menyediakan layanan rehabilitasi untuk yang menyandang Disabilitas mental.

Maka dari itu petugas Lapas berupaya semaksimal memenuhi kebutuhan bagi narapidana penyandang disabilitasi di Lapas Kelas 1 Madiun:

- Pihak Lapas memberikan pelayanan publik berupa aksesbilitas seperti disediakan jalur khusus bagi narapidana penyandang disabilitas, kursi roda, toilet khusus

- Rambu-rambu jalan di dalam lapas

- Mobil dan ambulance bagi narapidana disabilitas

- Adanya system jemput bola dimana petugas klinik melakukan kontrol keliling dengan jadwal yang telah ditentukan guna memantau kondisi kesehatan narapidana penyandang disabilitas

- Petugas berupaya memberikan keterampilan bagi narapidana penyandang disabilitas untuk memberikan skill kepada mereka sesuai keterampilan yang dapat mereka kerjakan.

- Adanya sosialisasi bagi narapidana lain agar tidak membuat eksploitasi, bullying kepada narapidana penyandang disabilitas

Dengan adanya fasilitas pelayanan bagi narapidana disabilitas diharapkan agar meminimalisir gangguan atau hambatan dengan kondisinya yang kurang agar bisa meningkatkan kesiapsiagaan untuk bergerak, berjalannya program pembinaan dan komunikasi antar narapidana

\section{KESIMPULAN}

Warga binaan penyandang disabilitas membutuhkan kebutuhan khusus bukan perlakuan khusus dalam menjalani masa pidana. Dikatakan kebutuhan khusus yaitu aksesbilitas, sedangkan kebutuhan yang setara dengan orang pada umumnya yaitu kebutuhan jasmani, seperti makan, sandang, papan, pekerjaan, kesehatan. Melihat situasi dan kondisi warga binaan penyandang disabilitas di Lapas Kelas 1 Madiun tentu dalam pelayanan yang diberikan sudah cukup optimal dalam pelayanan aksesbilitas bagi mereka. Dengan mengetahui kebutuhan yang menyandang diabilitas dengan jelas maka dapat dijadikan patokan dalam pelayanan dan rehabilitasi sehingga tujuan warga binaan yang menyandang disabilitas dapat melaksanakan kegiatan sosial pada umumnya dan mandiri sesuai kondisinya dengan mengikuti program-program pembinaan yang diberikan oleh Lapas.

\section{UCAPAN TERIMAKASIH}

Ucapan terima kasih diucapkan kepada Kepala Lembaga Pemasyarakatan Kelas I Madiun serta jajaran, dan juga kepada pihak yang telah membantu melancarkan penelitian saya. Kepada dosen Politeknik Ilmu Pemasyarakatan yang telah membimbing dalam penelitian ini hingga dapat terselesaikan tepat waktu.

\section{DAFTAR PUSTAKA}

Andriani, H. F., \& Subroto, M. (2021). Perlakuan Terhadap Narapidana Disabilitas Dalam Lembaga Pemasyarakatan. 5 , 6061-6069.

Herliansyah, A. R. (2020). NUSANTARA : Jurnal Ilmu Pengetahuan Sosial IMPLEMENTASI PEMBERIAN HAK PELAYANAN KESEHATAN. 7(1), 212-221. 
Website : http://sosial.unmermadiun.ac.id/index.php/sosial

Hikmawati, E., \& Rusmiyati, C. (2011). Kebutuhan Pelayanan Sosial Penyandang Cacat. Sosio Informa, 16(01), 17-32.

Kristiandy, F. (2021). Analisis Kesejahteraan Hak Penyandang Disabilitas : Situasi , Kondisi , Permasalahan Dan Solusi Penyandang Pemasyarakataan. Jurnal Hukum, 4(1), 125-133.

Ramadhan, M. S., \& Novianti, D. (2018). DISABILITAS.

Soemari, Y. B., Sapri, Maghfiroh, F., Yuniarti, Achaditani, N. M., Variani, R., Tsabitah, A. F., Zulkarnain, A. K., Wahyuningsih, M. S. H., Nugrahaningsih, D. A. A., Akmaliyah, M., Syamsul, E. S., Amanda, N. A., Lestari, D., 2021, scmidt iotc, Sumule, A., Kuncahyo, I., Leviana, F., Xue-, W., Kimia, J. T., ... Jubaidah, S. (2020). No 主観的健康感を 中心とした在宅高齢者における 健康関連指標に関する共分散構造分析Title. Journal of Chemical Information and Modeling, 2(1), 5-7.

http://jurnal.globalhealthsciencegroup.com/index.php/JPPP/article/download/83/65\%0Ahttp://www.embase.com/search/re sults?subaction=viewrecord\&from=export\&id=L603546864\%5Cnhttp://dx.doi.org/10.1155/2015/420723\%0Ahttp://link.s pringer.com/10.1007/978-3-319-76887- 